\title{
MONGOLOID POPULATIONS FROM THE VIEWPOINTS OF Gm PATTERNS
}

\author{
Hideo Matsumoto, ${ }^{1}$ Tokiko Miyazaki, ${ }^{1}$ Nakao Ishida, ${ }^{2}$ \\ and Kazumichi KATAYAMA ${ }^{3}$ \\ ${ }^{1}$ Department of Legal Medicine, Osaka Medical School, Takatsuki, \\ Osaka 569, Japan \\ ${ }^{2}$ Department of Bacteriology, Tohoku University School of \\ Medicine, Sendai 980, Japan \\ ${ }^{3}$ Laboratory of Physical Anthropology, Faculty of Science \\ Kyoto University, Kyoto 606, Japan
}

\begin{abstract}
Summary Gm systems provide unique markers for the study of human genetics, especially for the characterization of a population, the study of gene flow, and genetic drift by the presence of a unique haplotype or by marked differences in the frequencies of identical haplotypes. It has been shown that $\mathrm{Gm}$ haplotypes commonly present among Mongoloids are $\mathrm{Gm}^{\mathrm{ag}}, \mathrm{Gm}^{\mathrm{axg}}, \mathrm{Gm}^{\mathrm{ab}}{ }^{3 \mathrm{st}}$, and $\mathrm{Gm}^{\mathrm{afb}} \mathrm{b}^{3}$.

The distribution of $\mathrm{Gm}$ allotypes has been investigated for the 16 Mongoloid populations from various regions in Asia, North, and South America. A striking aspect of the $\mathrm{Gm}$ data from the Mongoloid populations is the presence of a clear geographic cline, especially for the $\mathrm{Gm}^{\mathrm{ag}}$ and $\mathrm{Gm}^{\mathrm{afb}^{1} b^{3}}$ haplotypes from Southeast Asia through East Asia into South America. Moreover the Mongoloid populations were divided into two characteristic groups on the basis of the Gm patterns. A geographic cline was also found for the $\mathrm{Gm}^{\mathrm{ab}}{ }^{\text {sst }}$ haplotype which is a marker gene of Mongoloids. Discussion was made for the reason why and how such clear geographic cline of the Gm haplotypes has been occurred in the Mongoloid populations.
\end{abstract}

\section{INTRODUCTION}

Morphological characters have long been used to classify human beings into races. As is well known, the human ABO blood group was discovered in 1900 by Landsteiner. The ABO blood group was applied for the first time by Hirszfeld and Hirszfeld (1919) to human classification on the basis of the fact that the blood group was inherited as a Mendelian character and that the blood group frequencies differed systematically and significantly between different populations. This opened

Received April 15, 1982 
the field for a new approach to anthropology. Since then hundreds of thousands of blood groups have been done for anthropological reasons. Many of the systems reviewed by Mourant et al. (1976) have been used to characterize human populations, but none of them can do so individually. This distinction is presently limited to the Gm systems, but recent work indicates that the HLA groups may prove to be equally effective, although the necessary data are not yet available (Steinberg and Cook, 1981).

In 1956 Grubb discovered individual differences in human gamma-globulin detected by a serological reaction. He noticed that the serum of a patient with hypogammaglobulinemia would agglutinate red cells sensitized with incomplete anti-Rh antibody. He further observed that this agglutination could be inhibited by some normal sera and not by others, and this led to the discovery of the Gm (gamma marker) system.

During the two decades since Grubb discovered the $\mathrm{Gm}(\mathrm{a})$ factor, a great number of genetic markers of human immunoglobulins have been described. It has been found that these genetic markers are all located on the constant region of the molecule. On the basis of the fact that the allotypic defferences are related to the one single amino acid substitution, these genetic markers are thought to originate from single-step mutations of existing genes.

Genetic markers of $\operatorname{IgG}$ are inherited in fixed combinations referred to as haplotypes, that is, in patterns reminiscent of the Rh and HLA systems. Gm systems provide unique markers for the study of human genetics, especially for the characterization of a population, the study of gene flow and genetic drift by the presence of a unique haplotype (some haplotypes are absent from or confined to certain races), or by marked differences in the frequencies of identical haplotypes.

The $G m(t)$ which was discovered in the specific antisera from a few individuals in Nose Village of Toyono, Osaka, was described together with the $\mathrm{Gm}(\mathrm{s})$ which was discovered in the Netherlands (Mårtensson et al., 1966). Further, the Gm(st) was recognized to be expressed by the marker gene, $\mathrm{Gm}^{\mathrm{st}}$ of Mongoloid populations (Matsumoto and Takatsuki, 1968; van Loghem et al., 1970). It was described that the nine Gm phenotypes observed in Japanese populations are explained by the presence of the four haplotypes, $\mathrm{Gm}^{\mathrm{ag}}, \mathrm{Gm}{ }^{\mathrm{axg}}, \mathrm{Gm}^{\mathrm{ab}} \mathrm{b}^{3 \mathrm{st}}$, and $\mathrm{Gm}^{\mathrm{afb} b^{3}}$ (Matsumoto and Takatsuki, 1968).

For fifteen years since then, the distribution of Gm allotypes have been investigated in our laboratory using series of serum samples from various ethnic groups of various regions in Asia, North, and South America. Some of the serum samples were collected by ourselves on the spot and some were obtained through the courtesy of friends. The present paper has a restricted aim, namely to wrap up further the $\mathrm{Gm}$ data of the Mongoloid populations from Asia to South America accumulated in these years, including the published and unpublished data. First of all attention will be drawn to some features of the Gm haplotype distribution among these populations. 


\section{POPULATIONS}

Japanese population. Eleven Japanese populations from Hokkaido to Kyushu have been investigated for the $\mathrm{Gm}$ systems. The test for heterogeneity among these populations showed them to be homogenous $\left(\chi_{20}{ }^{2}=9.21 ; .97>p>.95\right)$, and accordingly, the data of Osaka district was used as the Japanese population in this study.

Okinawan and Korean populations. The Okinawan population investigated was that inhabiting Miyako and Yaeyama Islands; the Korean population studied here was that inhabiting Cheju Island. After the investigation of that population was done, seven further Korean populations from Kannung, Wonju, Kyongju, Chonju, Pusan, Kwangju, and Cheju Island were tested. Data showing these populations to be homogenous was obtained $\left(\chi_{21}{ }^{2}=12.18 ; .95>p>.90\right)$ (Matsumoto et al., 1980).

Ainu population. The Ainu in Hokkaido have been referred to as a race on the verge of disappearing. On the one hand, the Ainu are losing their traditional culture due to their gradual assimilation into Japanese society, and the other hand, the pure Ainu population is markedly decreasing through intermarriage with Japanese. The population surveyed here is of Ainu living in the Hidaka area of Hokkaido, where most of the Ainu live. Racially pure Ainu are now thought to be very few. This estimation of Ainu racial purity was made on the basis of official records and, in most cases, through direct or indirect information obtained from the old men of the village and from school teachers. The purity of the Ainu was assessed by averaging the individual Ainu purity estimated from the average parental purity values. Thus, it was concluded that the Ainu population investigated in this study is approximately 60 to $70 \%$ genetically pure, the amounts of Japanese admixture being estimated at from 30 to $40 \%$ (Matsumoto and Miyazaki, 1972).

Taiwanese population. 'Taiwanese' as so termed, are all immigrants from mainland China. Most of them moved there in about the 17 th to 18 th centuries, and it has been estimated that $80 \%$ came from Fukien and $15 \%$ from Kwantung. Linguistically, the local dialect used in Taiwan is the same as that in southern Fukien (Manan-Yu). Both the people from Fukien and Kwantung belong to the Han race, as do most populations in mainland China. The landing places for the first immigrants in the earliest time, about the 17 th century, were in southern Taiwan, Tainan, and in the same period they also moved into central Taiwan, in the Taichung area. Consideration of the culture, customs, and social structure of the Taichung people shows them to be just the same as that of the southerner of mainland China. The Taiwanese population is of the people in Taichung area, excluding the people who moved in from mainland China after World War II (Matsumoto et al., 1975a).

Takasago population. 'Takasago' was the general term for the mountain aborigines of Taiwan. Since the latter half of 15 th century, it has been clear that these people belong to the Indonesian group among the Malay-Polynesian language groups. The language groups are believed to have moved out and spread in several

Vol. 27, No. 3, 1982 
migrations from the Southeastern Asiatic Continent to the Philippines and the East Indias and then further on to Oceania and, in another direction, to Madagascar, east of Africa.

The Takasagos living in the mountains and on the plains of the east coast and on Orchid Island are usually divided into nine tribes, the Atyal, Puyuma, Bunun, Tsou, Rukai, Paiwan, Saisyat, Ami, and Yami. The data of Takasago was concerned with the three endogamous Atyal, Bunun, and Paiwan tribes. These people live in a mountainous area more than one thousand meters above sea level along the upper and middle valleys of the Taiwan Mountains. There are no great differences between the three tribes regarding their shifting cultivation method of farming, their mode of hunting, and their natural environment. However, they differ markedly in social structure, tradition, and language. The Atyal, for example, are said to be the only Takasago people who do not possess the technique of making pottery. They use gourd and bamboo instead of clay for making vessels and containers. Though the tribes practice endogamy, the possibility of some mixture at one time or another cannot be entirely excluded. There were no significant differences in the Gm haplotype frequencies between the Atyal, Bunun, and Paiwan (Matsumoto et al., 1972).

Indonesian populations. According to Coon (1969), the Neolithic inhabitants of Southeast Asia were mainly a mixed group of Australoid and Mongoloid origin, with pockets of Negritos much more widespread than they are today. The Indonesians who live west of Wallace's Line are similar to the less Mongoloid of the Southeast Asians, and less Australoid than the Cambodians. They represent a more or less stable mixture between Mongoloid and Australoid elements, with local variations. Howells (1973) suggests also that Indonesians are predominantly of the Malaysian race who have an Austronesian (Malay-Polynesian) base linguistically. The populations studied here were of Indonesians in Java and on Banggai Island. The principal ethnic groups in the area are said to be Sundanese and Javanese (Matsumoto et al., 1975b).

Negrito populations. The Negrito or Oceanic Pygmies are probably the oldest living aborigines, and live in scattered groups on the archipelago in Southeast Asia. Phylogenic relationships of the Negritos, however, remain obscure. Most Negritos (also known as Aetas) inhabit Luzon Island, but a small group, known as Mamanwas, live on the northernmost part of Mindanao Island. The Negrito blood samples were collected from unrelated individuals in Zambales, Luzon and in the Province of Agusan del Norte, northern Mindanao (Matsumoto et al., 1979).

Kadazan population. Williams (1965) described in the monograph "The Dusan: A North Borneo Society," the Dusans are also called Kadazans. The first to come to Borneo probably was of a type often called "Negrito." About 15,000 to 20,000 years ago there was a series of movements of a population out from South China into Southeast Asia. It appears that most of the present Borneo native populations are derived from several Indo-Malayan migrations to the island. The 
earliest migation of a food-raising Indo-Malayan population to Borneo calme with movement from South China and Noth Vietnam, through Formosa and the Philippines, of a people whose typical tool was a stone adze made in a lozenge cross section. Following this time, probably between 1,500 to $1,000 \mathrm{~B}$.C., two closely related populations of Indo-Malayan food raisers, both using a quadrangular-sectioned adze, moved into Borneo from opposite difections. Physically, inguistically, and culturally the Kadazans of North Boneo have more in common with a number of native groups in the Philippines and Formosa than with native people in nearby Sarawak and Indonesian Bornee. The serum samples from the Kadazans were provided by Dr. Y. Teng (IMR, University of California, ICMRT, Kuala Rutopur, Malaysia).

Alaskan Eskimo and Athaboscan Indian populations. The sefum samples from the Alaskan Eskimos and Athabascan Indians were obtained through the courtesy of Br. B. Blumberg. The Eskimos were all from nothern dialect speakers who lived in wainwright, Barrow, and near Summit Lake in Anaktuvuk Pass in the Brooks Range. The northern Athabascan-speaking Indians were from Arctic Village, Brooks Range, Fort Yukon and Beaver. The majority of the aborigines tested were recorded as full-blooded in the census records, and were regarded as being so in their communities. Howerer, in Wainwright and Fort Yukon approximately $15 \%$ were listed as more than hall but less than full-blooded.

Pina Indian population. The Gm data of Pima Indians fom Arizona, U.S.A. was oftained through the courtesy of D. A.G. Steinberg.

Seruvian Indian populations. The samples were collected form the Indians residing among the Andes Mountains and form the Indians living in the bonch areas of the Amazon River. In the former, the samples consist of a total of 96 Quechuan Indians (44 from Katanga, 1 from Mollepata, 51 from Socos). In the latter, the samples consist of 250 Indians (106 Machiguenga, 70 Pio, 51 Amahuaca, $16 \mathrm{Campa}$, and 7 Yaminahua). There were significant differences of the Gm haplotype frequencies between the Andes and Amazon Indians $\left(\chi_{3}{ }^{2}=45.06 ; p<.001\right)$ (Matsuimoto etal., 1975).

\section{METHODS}

The reagents used for the Grosts and the numeric and alphabetic nomenclature are presented in Table 1. The tests were done by methods previously described (Matsumoto and Takatsuki, 1968).

\section{RESULTS ANI BISCUSSION}

The Grm haplotypes commonly presentamon Caucasoids of unmixed ancestry

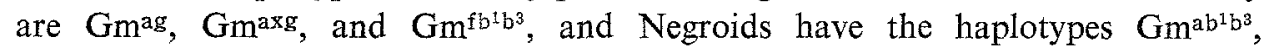

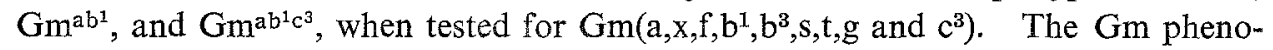


Table 1. Reagents used for Gm allotype determination.

\begin{tabular}{|c|c|c|c|}
\hline \multicolumn{2}{|c|}{ Allotype notmenclature } & \multirow{2}{*}{ Anti-allotype } & \multirow{2}{*}{ Anti- $\mathrm{Rh}_{0}$} \\
\hline Alphabetic & Numerical & & \\
\hline \multirow[t]{4}{*}{ G1m a } & 1 & 3552 & 2880 \\
\hline & & 3294 & 3417 \\
\hline & & Mor & Bra \\
\hline & & 2130 & 3069 \\
\hline \multirow[t]{4}{*}{$x$} & 2 & 2984 & 2880 \\
\hline & & Tyl & Ham \\
\hline & & 2135 & 2337 \\
\hline & & 2135 & 2880 \\
\hline \multirow[t]{3}{*}{$\mathrm{f}$} & 3 & 2871 & Kover Root \\
\hline & & 2871 & 3097 \\
\hline & & A.J. & Ho568 \\
\hline \multirow[t]{4}{*}{$\mathrm{G} 3 \mathrm{~m} \mathrm{~b}^{\mathbf{1}}$} & 5 & 7514 & 3656 \\
\hline & & 2933 & 2127 \\
\hline & & Pay & 107 \\
\hline & & Ben & 3419 \\
\hline \multirow[t]{4}{*}{$b^{3}$} & 13 & 4721 & 3656 \\
\hline & & 2277 & 2127 \\
\hline & & Ing & 107 \\
\hline & & Hou & 3419 \\
\hline \multirow[t]{3}{*}{$\mathrm{g}$} & 21 & 1642 & 3359 \\
\hline & & 5306 & 3359 \\
\hline & & Monkey E & Ham \\
\hline \multirow[t]{2}{*}{$\mathrm{s}$} & 15 & 2624 & 3068 \\
\hline & & 2624 & Vai \\
\hline \multirow[t]{3}{*}{$\mathrm{t}$} & 16 & $\mathrm{R}-36$ & 3068 \\
\hline & & 2639 & 3068 \\
\hline & & Monkey Geo & Vai \\
\hline \multirow[t]{3}{*}{$c^{3}$} & 6 & Har & Kre \\
\hline & & Cur & Con \\
\hline & & Cur & War \\
\hline
\end{tabular}

type and haplotype frequencies observed among the Mongoloid populations are shown in Tables 2 and 3. This data indicates that their haplotypes are Gmag, $\mathrm{Gm}^{\mathrm{axg}}, \mathrm{Gm}^{\mathrm{afb} b^{1} \mathrm{~b}^{3}}$, and $\mathrm{Gm}^{2 \mathrm{~b}^{3} \mathrm{st}}$, and that three to nine phenotypes which are accounted for by the presence of either three or four of these haplotypes were observed among these populations. The surprising heterogeneity in the $\mathrm{Gm}$ haplotype frequencies was detected. As shown in Table 3, the precipitous drop between Japan 
Table 2. Gm phenotype frequencies among the Mongoloid populations.

\begin{tabular}{|c|c|c|c|c|c|c|c|c|c|c|}
\hline & $\mathrm{ag}$ & $\mathrm{agb}^{3} \mathrm{st}$ & $\operatorname{axg}$ & $a g f b^{1} b^{a}$ & $\operatorname{axgb}^{3} \mathrm{st}$ & $a f b^{1} b^{3} s t$ & $a b^{3} s t$ & $a x g f b^{1} b^{3}$ & $a f b^{x} b^{3}$ & Tota1 \\
\hline Quechuan (Peru) & 72 & 3 & 16 & 4 & 0 & 0 & 0 & 1 & 0 & 96 \\
\hline Machiguenga (Peru) & 137 & 0 & 110 & 0 & 0 & 0 & 1 & 2 & 0 & 250 \\
\hline Pima (Arizona) & 2,051 & 29 & 270 & 128 & 1 & 0 & 0 & 3 & 0 & 2,482 \\
\hline Athabascan (Alaska) & 38 & 18 & 30 & 7 & 9 & 2 & 1 & 3 & 0 & 108 \\
\hline Eskimo (Alaska) & 107 & 90 & 0 & 13 & 2 & 6 & 10 & 3 & 1 & 232 \\
\hline Ainu (Hokkaido) & 132 & 111 & 71 & 19 & 32 & 9 & 26 & 4 & 2 & 406 \\
\hline Korean (Cheju Is.) & 69 & 67 & 70 & 25 & 28 & 12 & 16 & 10 & 3 & 300 \\
\hline Japanese (Osaka) & 72 & 82 & 54 & 37 & 34 & 25 & 19 & 13 & 7 & 343 \\
\hline Japanese (Okinawa) & 65 & 79 & 84 & 24 & 41 & 15 & 25 & 12 & 3 & 348 \\
\hline Taiwanese (Taichung) & 15 & 8 & 12 & 83 & 3 & 16 & 0 & 29 & 120 & 286 \\
\hline Takasago (Taiwan) & 15 & 0 & 10 & 143 & 0 & 2 & 0 & 28 & 270 & 468 \\
\hline Indonesian (Java) & 2 & 0 & 7 & 37 & 0 & 2 & 0 & 34 & 101 & 183 \\
\hline Indonesian (Banggai) & 1 & 0 & 0 & 22 & 0 & 0 & 0 & 12 & 42 & 77 \\
\hline Negrito (Luzon) & 12 & 0 & 12 & 48 & 0 & 0 & 0 & 10 & 42 & 124 \\
\hline Negrito (Mindanao) & 2 & 0 & 8 & 14 & 0 & 0 & 0 & 27 & 42 & 93 \\
\hline Kadazan (Borneo) & 0 & 0 & 0 & 7 & 0 & 0 & 0 & 6 & 227 & 240 \\
\hline
\end{tabular}

Table 3. Gm haplotype frequencies among the Mongoloid populations.

\begin{tabular}{lllll}
\hline & ag & axg & ab $\mathrm{st}^{3}$ & $\mathrm{afb}^{\mathrm{2}} \mathrm{b}^{3}$ \\
\hline Quechuan (Peru) & 0.865 & 0.093 & 0.016 & 0.026 \\
Machiguenga (Peru) & 0.735 & 0.257 & 0.004 & 0.004 \\
Pima (Arizona) & 0.909 & 0.057 & 0.006 & 0.026 \\
Athabascan (Alaska) & 0.468 & 0.333 & 0.143 & 0.056 \\
Eskimo (Alaska) & 0.683 & 0.011 & 0.254 & 0.052 \\
Ainu (Hokkaido) & 0.563 & 0.093 & 0.252 & 0.043 \\
Korean (Cheju Is.) & 0.483 & 0.199 & 0.231 & 0.087 \\
Japanese (Osaka) & 0.450 & 0.157 & 0.262 & 0.129 \\
Japanese (Okinawa) & 0.434 & 0.221 & 0.262 & 0.083 \\
Taiwanese (Taichung) & 0.222 & 0.087 & 0.047 & 0.643 \\
Takasago (Taiwan) & 0.194 & 0.042 & 0.002 & 0.762 \\
Indonesian (Java) & 0.127 & 0.116 & 0.005 & 0.751 \\
Indonesian (Banggai) & 0.156 & 0.078 & 0.000 & 0.766 \\
Negrito (Luzon) & 0.136 & 0.100 & 0.000 & 0.754 \\
Negrito (Mindanao) & 0.120 & 0.208 & 0.000 & 0.672 \\
Kadazan (Borneo) & 0.015 & 0.012 & 0.000 & 0.973 \\
\hline
\end{tabular}

Vol. 27, No. 3, 1982 
and Taiwan and regular decrease towards South America in the Gmafb1 $\mathrm{b}^{3}$ haplotype frequency were demonstrated. The opposite feature was demonstrated in the Gmga haplotype frequency.

In marked contrast to the differences observed in the $\mathrm{Gm}^{\mathrm{afb}^{1} \mathrm{~b}^{3}}$ and $\mathrm{Gmga}$ haplotype frequencies, the $\mathrm{Gm}^{\text {abst }}$ haplotype frequency was the highest among Japanese, Korean, Ainu, and Alaskan Eskimo, and declines sharply in Athabascan Indian and then reached the minimum in South American Indians. On the other hand, the haplotype was detected in extremely low frequency among Taiwanese, Takasagos and Indonesian from Java but not among Indonesian from Banggai, Negritos from the Philippines and Kadazan from Borneo at all.

Again, a striking aspect of the Gm data from these Mongoloid populations is the presence of a clear geographic cline, especially for the $\mathrm{Gm}^{\mathrm{ag}}$ and $\mathrm{Gm}^{\mathrm{afb}} \mathrm{b}^{1} \mathrm{~b}^{3}$ haplotypes from Southeast Asia through East Asia into South America. And the Mongoloid populations can be divided into two groups; one is a "Northerner Group" which is characterized by a high frequency of the Gmag haplotype and a very low frequency of the Gm $\mathrm{afb}^{1 \mathrm{~b}^{3}}$ and the other is a "Southerner Group" characterized by a remarkably high frequency of the $\mathrm{Gm}^{\mathrm{afb}^{1} \mathrm{~b}^{3}}$ and lower frequency of the $\mathrm{Gm}^{\mathrm{ag}}$. A geographic cline was also found for the $\mathrm{Gm}^{\mathrm{ab}}{ }^{3} \mathrm{st}$ haplotype which is a marker gene for Mongoloids from Japan and Korea to Southeast Asia and to South America. Thus, there seems to be sufficient evidence to assume the past existence of two distinct Mongoloid populations among the paleomongoloid population of East Asia.

It is generally accepted that resemblances in languages are of considerable historical significance since they indicate a common origin in the past followed by subsequent differentiation. This is the product of historical forces that tend to isolate, in particular population movements or migration. The material culture of migrating groups tends to change rapidly as they adapt to new natural and social environments, but languages are much more resistant to change. Analysis of language relationships therefore provides clues to prehistoric population movements.

In this sense, the Northerner Group of the Gm pattern corresponds to the Ural-Altain language group, the mounted nomads known as Timour and Huns linguistically. Similarly, the Southerner Group of the Gm pattern corresponds to the Tibetan-Sinitic and Austronesian language groups. The Han race, the principal component of the Tibetan-Sinitic language group is considered to have lived in the middle basin of the Yellow River as a farming and gathering people called proto-Chinese and then to have gradually spread over South and Southeast Asia, oppressing their neighbors and assimilating with them. On the other hand, the Austronesian language group is conventionally divided into four groups, Indonesian, Polynesian, Melanesian, and Micronesian, distributed over a wide area from Madagascar to Easter Island and from Taiwan to New Zealnd. According to Howells (1973), dispersal of Austronesian language groups began about 4,000 B.C. from an unknown region in or adjacent to South China, spreading through Indonesia 
and beyond New Guinea into Island Melanesia and Micronesia by 1,000 B.C. The center of distribution, at any rate, is in Southeast Asia where paleo-Mongoloids are supposed to be predominantly mixed with Negritos and Aboriginal groups.

American Indians are generally classified as Mongoloids. According to Sanders and Marino (1970), the first migration across the Bering Strait from Siberia, the most obvious specific point of departure, probably lasted a long time and occurred in at least three phylum groups that brought first the ancestors of the Macro-CaribGe speakers, then, in succession, Macro-Arawakan-Quechuan and the Macro-Maya speakers into the New World between 20,000 and 40,000 years ago. The more specialized Mongoloids, known as Eskimo and $\mathrm{Na}$-Dene speakers, arrived later, between 6,500 and 4,000 B.C. The veneer of Mongoloid traits found in the more southern groups is presumably a product of a later gene flow from north to south.

The Peruvian Indians investigated here were considered to be descendants of the Macro-Arawakan-Quechuan phylum, who were supposed to have migrated into South America from Northern Asia before 20,000 B.C. in at least one of the earliest waves of population movement. The $\mathrm{Gm}$ pattern of these populations is, except for extremely low incidence of the $\mathrm{Gm}^{\mathrm{ab}}{ }^{3} \mathrm{st}$ haplotype, that characterizes northern Mongoloid populations, as it should be. The Peruvian Indians who are said to be less specialized Mongoloids on the basis of linguistic and biological evidence, have an extremely low frequency of the Gmab3st gene characteristic of Mongoloids. This suggests that the South American Indians may not have had the $\mathrm{Gm}^{\text {ab }}{ }^{3}$ st gene originally and that it was introduced through later gene flow from north to south by much more specialized Mongoloids who arrived prior to the development of productive agriculture, namely, prior to the formation of settled communities, much later from Siberia. It may also indicate the time when the $\mathrm{Gm}^{\mathrm{ab}}{ }^{3 \mathrm{st}}$ gene arose. On the basis of the data mentioned above, it must assumed that the Gmafb1b haplotype found among the Northerner group presumably was introduced by the Southerner group, on the contrary, $\mathrm{Gm}^{\mathrm{ab}}{ }^{3} \mathrm{st}$ haplotype found among the Southerner group was introduced by the Northerner group in relatively recent time.

The degree of inter-population differentiation can be roughly measured for each haplotype, using the fixation index $\left(\mathrm{F}_{\mathrm{ST}}\right)$ by Wright $(1951)$. The $\mathrm{F}_{\mathrm{ST}}$ estimates were $0.313,0.070,0.151$, and 0.348 for the $\mathrm{Gm}^{\mathrm{ag}}, \mathrm{Gm}^{\mathrm{axg}}, \mathrm{Gm}^{\mathrm{ab} \mathrm{s}^{\mathrm{st}}}$, and $\mathrm{Gm}^{\mathrm{afb} \mathrm{b}^{3}}$ haplotypes, respectively, and the unweighted average was 0.221 , indicating that the degree of differentiation among populations concerned was very great and almost equivalent to those of worldwide differentiation for the $\mathrm{Rh}$, Duffy, and $\mathrm{Gm}$ systems reported by Cavalli-Sforza (1966). Further, the heterogeneity of $F_{S T}$ remains a possibility that the differentiation of $\mathrm{Gm}$ haplotype frequencies, especially in the $\mathrm{Gm}^{\mathrm{ag}}$ and $\mathrm{Gm}^{\mathrm{afb} \mathrm{b}^{3}}$, has occurred largely by other factors rather than random genetic drift, for example, gene flow and selection.

The results of considering the observed genetic differentiation between the populations investigated were examined by the genetic distance of Nei (1972) based on the Gm data. The matrix of the genetic distance between the sixteen popula- 


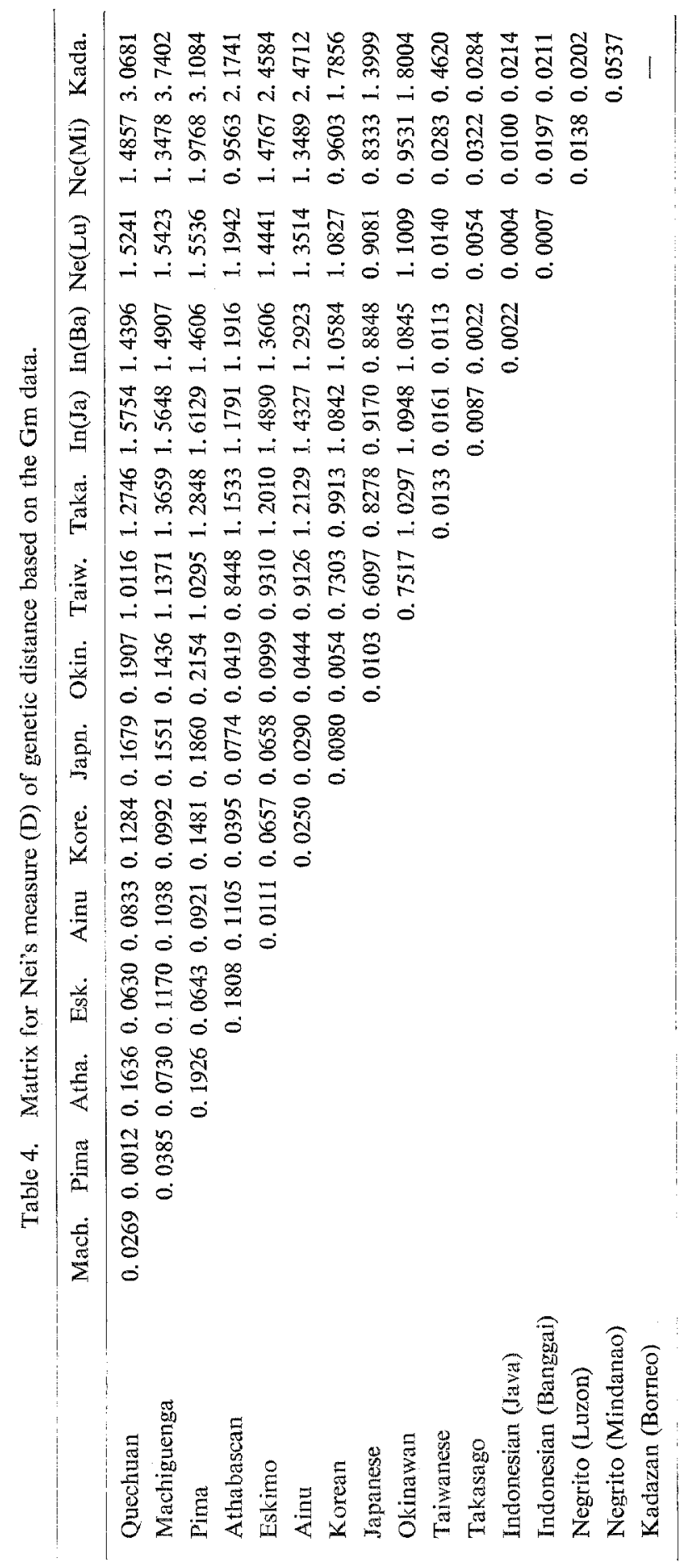




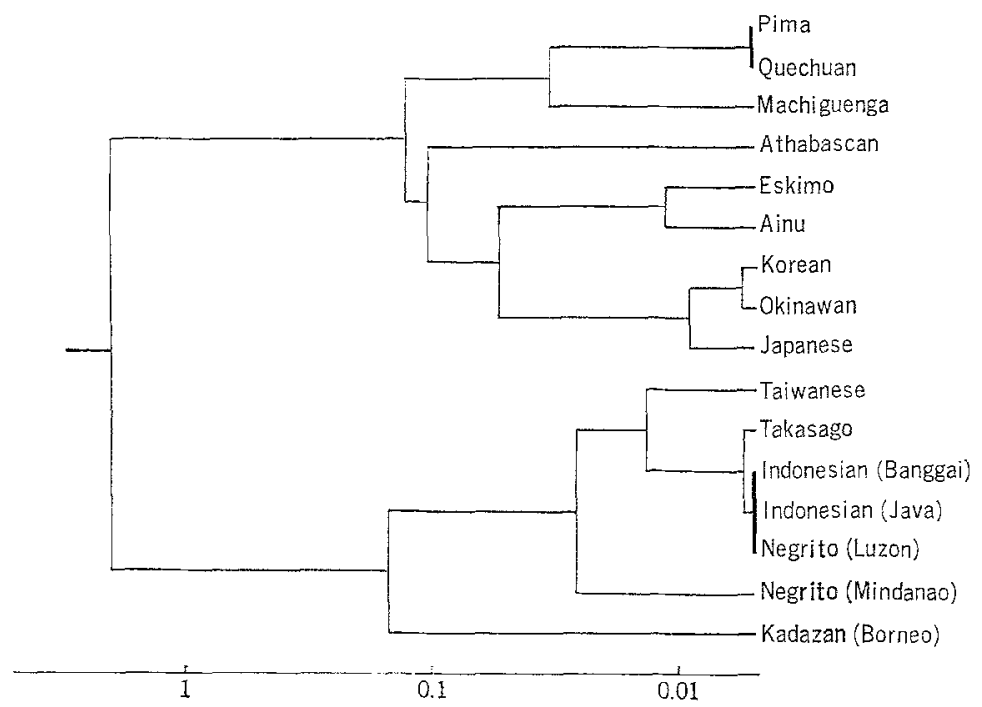

Fig. 1. Dendrogram from Nei's genetic distances between the Mongoloid populations based on the $\mathrm{Gm}$ data.

tions is given in Table 4. The maximum distance is between Kadazan in Borneo and Peruvian Indians. The minimum distances are between Pima and Quechua Indian and between Indonesian from Java, Indonesian from Banggai, and Negrito from Luzon. The values obtained in the distance analysis may be used to construct a dendrogram between the populations (Fig. 1). The construction was done by the method proposed by Nei (1975). As shown also by the distance matrix, the dendrogram indicates that Kadazan and American Indian groups are the most widely separated. The clustering indicates that Korean, Okinawan, and Japanese are clustered with Ainu and Eskimo, and the Taiwanese from South China is clustered with Takasago and Indonesians. It shows also that the Mongoloid populations are split into two distinct clusters, one of which is a cluster of the populations from Japan to South America and another is that from Taiwan to Southeast Asia, each of these being separated from each other by marked genetic distances, as indicating the existence of two centers of dispersion among Mongoloid populations in the past.

\section{REFERENCES}

Cavalli-Sforza, L.L. 1966. Population structure and human evolution. Proc. Roy. Soc. (London), B164: 362-379.

Coon, C.S. 1969. The Living Races of Man, Alfred \& Knopf, New York.

Hirszfeld, L., and Hirszfeld, H. 1919. Serological differences between the blood of different races.

The results of researchs on the Macedonian front. Lancet ii : 675-679.

Howells, W. 1973. The Pacific Istanders, Weidenfeld \& Nicolson, London. 
Mairtensson, L., vat Loghem, E., Matsumoto, H, and Nielsen, J. 1966. Gm(s) and Gm(t): genetic determinarts of human $\gamma$-globulin. Vox Sang. 11: 393418 .

Matsumoto, H, and Takatsuki, K. 1968 . Studies on the Gm factors of Jaknese poptation and

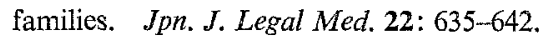

Matsumoto, H., and Miyazaki, T. 1972. Gm and Inv allotypes of the Ainu in Hidaka area, Hok-

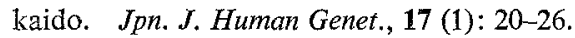

Matsumoto, H., Miyazaki, T., Fong, J.M., and Mabuchi, Y. 1972. Gm and Inv allotypes of the

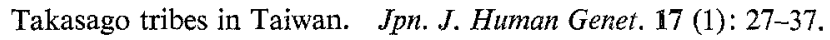

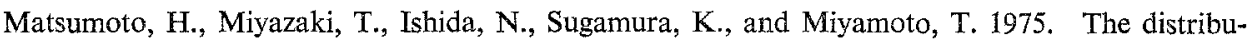

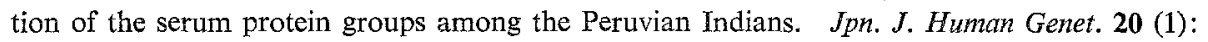
$51-52$.

Matsumoto, H., Miyazaki, T., and Lin, J.Y. 1975 a. Gm and Km allotypes of the Taiwatese. Jon. J. HAman Genet. 20 (2): $169-173$.

Matsumoto, H., Miyazaki, T., Lin, J.Y., and Hotta, S. 1975b. The serum protein groups of Inofonesians fom Java. Jph. J. Human Genet. 20 (3): 201-205.

Matsuimoto, H., Miyazaki, T., Omoto, K., Misawa, S., Harada, S., Hirai, M., Sthoaico, J.S., Medado, P.M., and Ogontuki, H. 1979. Population genetic studies of the Philippine Negritos. II Gm and Km allotypes of thee population groups. Am. J. Hum. Genet. 31: 71-76.

Matsumoto, H, Jamaki, Y., Miyazaki, T., Ohküa, K., Miyashita, T., and Kang, Y.S. 1980.

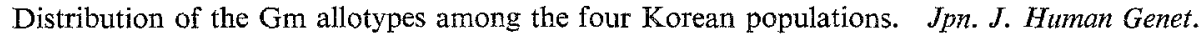
$25(2): 140-141$.

Mourant, A.F., Kopec, A.C., and Homoniewska-Sobczak, K. 1976. The Distribution of the Homon Blood Goups and Other Polymorphisms (2nd. edn.), Oxford University Press.

Nei, M. 1972. Genetic distance between populations. All. Natur. 106: 283-292.

Nei, M. 1975. Molecular Pophlation Genetics and Evolution, Noth-Hollaind, Amsterdam ato New York, pp. ${ }^{197-202 \text {. }}$

Sanders, W.T., and Marino, J. 1970. New World Mrehistow. Achaeology of the American Indian, Prentice Hall, Inc., New Jersey.

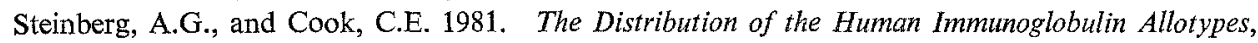
Oxford University Press.

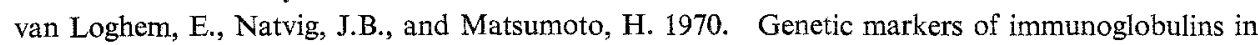
Japanese families. Inheritance of associated markers belonging to on $\operatorname{IgA}$ and thee IgG subclasses. Alth. Hom. Genet 33 : $351-355$.

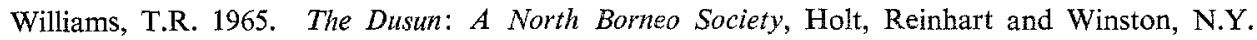
Wright, S. 1951. The genetical structure of populations. Ann. Ekten. 15: 323-354. 